Article

\title{
Subclade 2.2.1-Specific Human Monoclonal Antibodies That Recognize an Epitope in Antigenic Site A of Influenza A(H5) Virus HA Detected between 2015 and 2018
}

\author{
Moe Okuda ${ }^{1}$, Seiya Yamayoshi ${ }^{1, *\left(\mathbb{C}, \text { Ryuta Uraki }^{1}{ }^{1}, \text { Mutsumi Ito }^{1} \text {, Taiki Hamabata }\right.}{ }^{1}$ \\ and Yoshihiro Kawaoka 1,2,3,* \\ 1 Division of Virology, Department of Microbiology and Immunology, Institute of Medical Science, University \\ of Tokyo, Minato-ku, Tokyo 108-8639, Japan; 1923890575@edu.k.u-tokyo.ac.jp (M.O.); \\ r-uraki@med.nagoya-cu.ac.jp (R.U.); ito-mu@ims.u-tokyo.ac.jp (M.I.); hamabata@ims.u-tokyo.ac.jp (T.H.) \\ 2 Department of Special Pathogens, International Research Center for Infectious Diseases, Institute of Medical \\ Science, University of Tokyo, Minato-ku, Tokyo 108-8639, Japan \\ 3 Department of Pathobiological Science, School of Veterinary Medicine, University of Wisconsin-Madison, \\ Madison, Wisconsin 53706, USA \\ * Correspondence: yamayo@ims.u-tokyo.ac.jp (S.Y.); yoshihiro.kawaoka@wisc.edu (Y.K.)
}

Received: 11 March 2019; Accepted: 30 March 2019; Published: 2 April 2019

\begin{abstract}
Highly pathogenic avian H5 influenza viruses persist among poultry and wild birds throughout the world. They sometimes cause interspecies transmission between avian and mammalian hosts. H5 viruses possessing the HA of subclade 2.3.4.4, 2.3.2.1, 2.2.1, or 7.2 were detected between 2015 and 2018. To understand the neutralizing epitopes of H5-HA, we characterized 15 human monoclonal antibodies (mAbs) against the HA of $\mathrm{H} 5$ viruses, which were obtained from volunteers who received the $\mathrm{H} 5 \mathrm{~N} 1$ vaccine that contains a subclade 2.2.1 or 2.1.3.2 virus as an antigen. Twelve mAbs were specific for the HA of subclade 2.2.1, two mAbs were specific for the HA of subclade 2.1.3.2, and one mAb was specific for the HA of both. Of the $15 \mathrm{mAbs}$ analyzed, nine, which were specific for the HA of subclade 2.2.1, and shared the VH and VL genes, possessed hemagglutination inhibition and neutralizing activities, whereas the others did not. A single amino acid substitution or insertion at positions 144-147 in antigenic site A conferred resistance against these nine $\mathrm{mAbs}$ to the subclade 2.2.1 viruses. The amino acids at positions 144-147 are highly conserved among subclade 2.2.1, but differ from those of other subclades. These results show that the neutralizing epitope including amino acids at positions 144-147 is targeted by human antibodies, and plays a role in the antigenic difference between subclade 2.2.1 and other subclades.
\end{abstract}

Keywords: Influenza A virus; H5-HA; human monoclonal antibody; escape mutant virus

\section{Introduction}

The first human case of infection with a highly pathogenic avian H5N1 influenza virus was reported from Hong Kong in 1997 [1]. To date, 860 cases including 454 deaths have been recorded in 16 countries, mainly in Asia and Africa [2]. All of these cases were caused by viruses possessing H5-HA that originated from A/goose/Guangdong/1/1996 [3]. This lineage of viruses is classified into 10 clades, plus many subclades based on HA sequence similarity [3]. After 2015, H5 viruses classified into subclades 2.3.4.4, 2.3.2.1, 2.2.1 and 7.2 are mainly detected in Southeast Asia, Europe, and North America, Indonesia and Bangladesh, Egypt and Israel, and China, respectively [4-6]. In each of these regions, viruses continue to evolve independently. 
The reassortant $\mathrm{H} 5$ viruses possessing HA derived from subclade 2.3.4.4, and NA from viruses other than the N1 subtype appeared, and have been spread throughout the world by migratory birds [7]. One such reassortant, the H5N6 viruses, caused 14 human cases, indicating that we must pay attention to these reassortant viruses [8].

Twenty-two human monoclonal antibodies (mAbs) that specifically bind to H5-HA have been reported (Table 1) [9-18]. Ten clones (H5.3, H5.2, H5.9, H5.13, H5.31, H5.16, H5.22, H5.24, H5.36, and H5.7), which were obtained from humans who were vaccinated with a virus classified in clade 1 , bound to the H5-HA of clade 1, but did not bind to the H5-HA of the subclade 2.1.3.2 [11]. Clone H5.3 recognized epitopes in antigenic site A of $\mathrm{H} 5-\mathrm{HA}[10,11]$. The other 12 clones that were obtained from patients who were infected with an $\mathrm{H} 5$ virus classified in clade 1 or 2.3.4 showed neutralization activity against several H5 viruses classified in different subclades [9-18]. The epitopes of these clones mapped to various regions [11-17]. These human $\mathrm{mAbs}$ are useful for antigenic analyses of HA between subclades, or within a subclade, because sequence comparisons would not reveal antigenic variation. However, the epitopes on H5-HA have not been fully determined until now, because of the limited number of available human mAbs against H5-HA.

Table 1. The epitope and neutralizing breadth of the previously identified 22 human monoclonal antibodies (mAbs).

\begin{tabular}{|c|c|c|}
\hline Clone & Epitope (amino acids or region) & $\begin{array}{l}\text { Neutralization Activity against Viruses } \\
\text { of Clade/Subclade }\end{array}$ \\
\hline H5.3 & 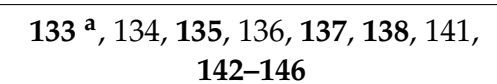 & 1 \\
\hline H5.2 & Head & 1 \\
\hline H5.9 & Head & 1 \\
\hline H5.13 & Head & 1 \\
\hline H5.31 & Head & 1 \\
\hline H5.16 & n.d. b & 1 \\
\hline H5.22 & n.d. & 1 \\
\hline $\mathrm{H} 5.24$ & n.d. & 1 \\
\hline H5.36 & n.d. & 1 \\
\hline H5.7 & Stem & 1 \\
\hline FLA5.10 & n.d. & 1 \\
\hline FLA3.14 & n.d. & 1 and 2.1.3.2 \\
\hline FLD21.140 & $126,127-128,168,169-171$ & $1,2.2$, and 2.3 .4 \\
\hline FLD20.19 & n.d. & 1 and 2.1.3.2 \\
\hline FLD194 & $\begin{array}{c}120-121, \mathbf{1 2 2}, 123, \mathbf{1 2 4}, 125, \mathbf{1 2 6}, \\
127-128\end{array}$ & $\begin{array}{c}0,1,2.1 .3 .2,2.2,2.2 .1,2.3 .2,2.3 .2 .1,2.3 .4 \\
\text { and } 2.5\end{array}$ \\
\hline FLD20 & n.d. & $0,1,2.1 .3 .2,2.2,2.2 .1,2.3 .4$, and 2.5 \\
\hline FLD84 & n.d. & $0,1,2.1 .3 .2,2.2,2.2 .1,2.3 .4$, and 2.5 \\
\hline $100 \mathrm{~F} 4$ & $\begin{array}{c}77-78,80-81,117, \mathbf{1 1 9}, 120-121 \\
\mathbf{1 2 2}, \mathbf{1 2 6}, 141, \mathbf{1 4 2}, 149,171-174 \\
258-259,261-262\end{array}$ & $\begin{array}{c}0,1,2.1 .3 .2,2.2 .1,2.3 .2 .1,2.3 .4 .4,2.4,2.5,3 \\
4,5,6,7,8, \text { and } 9\end{array}$ \\
\hline $65 \mathrm{C} 6$ & $\begin{array}{c}121, \mathbf{1 2 2}, 123,125, \mathbf{1 2 6}, 128-129 \\
162-163,165-167, \mathbf{1 6 8}, 169 \\
171-172,244,246\end{array}$ & $\begin{array}{c}0,1,2.1 .3 .2,2.2 .1,2.3 .4 .4,2.4,2.5,3,5,6,7 \\
8, \text { and } 9\end{array}$ \\
\hline $3 \mathrm{C} 11$ & n.d. & $\begin{array}{c}\text { 0, 2.1.3.2, 2.2.1, 2.3.2.1, 2.3.4.4, 2.4, 2.5, 3, 4, } \\
5,6,7,8 \text {, and } 9\end{array}$ \\
\hline AVFluIgG03 & $\begin{array}{c}\mathbf{1 3 0}-\mathbf{1 3 3}, \mathbf{1 3 4}, \mathbf{1 3 5}, \mathbf{1 3 6}, \mathbf{1 3 7}, 153 \\
155-159,190,193-194,222,225-226\end{array}$ & $0,2.1 .3 .2,2.2 .1,2.3 .4 .4,3,5,6,7,7.1$, and 9 \\
\hline AVFluIgG01 & $\begin{array}{l}120,123, \mathbf{1 2 4}, 125, \mathbf{1 2 6}, 127-128 \\
\mathbf{1 3 0}, 153,157,164-166,168,171\end{array}$ & $\begin{array}{c}0,1,2.1 .3 .2,2.2 .1,2.3 .2 .1,2.3 .4 .4,2.4,2.5,3 \text {, } \\
4,5,6,7,8 \text {, and } 9\end{array}$ \\
\hline
\end{tabular}

Previously, we obtained human broadly reactive mAbs from healthy human volunteers who received the $\mathrm{H} 5 \mathrm{~N} 1$ vaccine that contains the inactivated, adjuvanted whole-virion of A/Egypt/N03072/2010 (subclade 2.2.1) or A/Indonesia/5/2005 (subclade 2.1.3.2) [19]. In the process, 
we also found 15 human mAbs that specifically recognized H5-HA. Here, we characterized these mAbs to better understand the antigenicity of H5-HA.

\section{Materials and Methods}

\subsection{Ethics Statement}

Human blood was collected by the following protocols approved by the Research Ethics Review Committee of the Institute of Medical Science, at the University of Tokyo (25-58-1205 and 29-72-A0322). Informed consent was obtained from all participants.

\subsection{Cells}

Human embryonic kidney 293T cells were maintained in Dulbecco's modified Eagle's medium (DMEM) containing 10\% Fetal Calf Serum (FCS) and 1\% Penicillin/Streptomycin. Madin-Darby canine kidney (MDCK) cells were maintained in Eagle's minimal essential medium (MEM) containing 5\% newborn calf serum (NCS) and 1\% Penicillin/Streptomycin. These cells were incubated at $37^{\circ} \mathrm{C}$ under $5 \% \mathrm{CO}_{2}$. Cloned hybridomas expressing human antibodies were maintained in DMEM containing 15\% FCS and 1\% Penicillin/Streptomycin. Expi293 cells (Grand Island Biological Company (Gibco), Grand Island, New York State, USA) maintained in Expi293 expression medium (Thermo Fisher Scientific, Waltham, Massachusetts, U.S.) under serum-free conditions, were incubated on an orbital shaker platform rotating at $125 \mathrm{rpm}$ at $37{ }^{\circ} \mathrm{C}$ under $8 \% \mathrm{CO}_{2}$.

\subsection{Viruses}

H5 subtype viruses [A/gyrfalcon/Washington/41088-6/2014 (Washington; subclade 2.3.4.4, H5N8, EPI860648), A/chicken/Czech Republic/1688-171/2017 (Czech; subclade 2.3.4.4, H5N8, EPI1021136), A/chicken/Ghana/15VIR5480-7/2015 (Ghana; subclade 2.3.2.1, H5N1, EPI806495), A/duck/Menia/1543S/2015 (Menia; subclade 2.2.1, H5N1, EPI965960), and A/chicken/Wenzhou/HAYXLG03/2015 (Wenzhou; subclade 7.2, H5N2, EPI682905)] possessing conserved amino acid sequences within each subclade were selected as a representative isolate of each subclade. Attenuated nucleotide sequences of HA segments derived from these five isolates were synthesized and cloned into pHH21 for expressing vRNA. Based on the wild-type HA sequence of the Menia virus, the HA plasmid possessing a single amino acid mutation was generated by using the standard polymerase chain reaction (PCR) technique. The $\mathrm{pHH} 21$ plasmid encoding the attenuated wild-type or mutant HA segment, together with the other seven segments of a high-yield mutant of A/Puerto Rico/8/34 (H1N1 subtype) (HY-PR8) [20], was used to rescue the reassortant viruses [21]. At $48 \mathrm{~h}$ post-transfection, the culture supernatant containing the viruses was collected and then inoculated into the choriallantoic cavity of 10-day-old chicken eggs. After $72 \mathrm{~h}$ of incubation at $37^{\circ} \mathrm{C}$, the choriallantoic fluid was collected as a stock virus solution, and titrated by the use of a plaque assay, HA assay, and $\mathrm{TCID}_{50}$ (50\% tissue culture infectious doses) values in MDCK cells.

\subsection{Screening of Hybridomas Expressing Human Monoclonal Antibodies (mAbs)}

The hybridomas used in this study were obtained previously [19] by fusion of peripheral blood mononuclear cells (PBMCs), which were isolated from healthy volunteers vaccinated with the H5N1 vaccine [A/Egypt/N03072/2009 (subclade 2.2.1, H5N1) or A/Indonesia/5/2005 (subclade 2.1.3.2, H5N1)], with SPYMEG cells (MBL) [22]. In this study, 15 hybridomas producing antibodies that specifically bind to H5-HA, were used.

\subsection{Construction and Expression of Human mAbs}

Total RNA was extracted from the hybridomas and reverse transcribed. The target sequences were amplified by PCR using primers targeted to the variable region of the heavy chain and the light chain of the human antibody. The sequences of the heavy and light chains were cloned into the 
pEHX1.1 vector and pELX2.2 vector, respectively $[19,23,24]$. A plasmid encoding both the heavy and light chains was constructed and transfected into Expi293 cells by using Expi Fectamine 293 (Thermo Fisher Scientific, Waltham, MA, USA) according to the manufacturer's protocol.

At four days post-transfection, the human antibodies in the culture media were purified by using a Hi Trap rProtein A FF column (GE Healthcare, Chicago, IL, USA), and the automated chromatography system AKTA pure 25 (GE Healthcare, Chicago, IL, USA). The concentration of the purified antibodies was measured by using a BCA Protein Assay Kit (Thermo Fisher Scientific, Waltham, MA, USA).

\subsection{Enzyme-Linked Immunosorbent Assay (ELISA)}

Recombinant HA proteins (Sino Biological Inc., 1400 Liberty Ridge Drive, Suite 101, Wayne, PA 19087, USA, and No.31 Kechuang 7th St, LuDong Area, BDA, Beijing 100176, Peoples' Republic of China) of A/Egypt/N03072/2009 (H5N1, subclade 2.2.1), A/Indonesia/5/2005 (H5N1, subclade 2.1.3.2), A/California/07/2009 (H1N1pdm09), and B/Florida/4/2006 (Yamagata lineage) were used as antigens. Recombinant HA protein $(50 \mu \mathrm{L} /$ well, $0.1 \mu \mathrm{g} / \mathrm{mL})$ immobilized to a 96-well plate was incubated with either the culture supernatant of the hybridoma, or $1 \mu \mathrm{g} / \mathrm{mL}$ of human monoclonal antibodies (mAbs) $(50 \mu \mathrm{L} /$ well). The human mAbs bound to the antigen were detected by using Goat Anti-Human IgG labeled with horseradish peroxidase (HRP) and the substrate TMB (tetramethylbenzidine, Thermo Fisher Scientific, Waltham, Massachusetts, U.S.). Fifteen minutes after addition of the substrate, color development was stopped with $2 \mathrm{M} \mathrm{H}_{2} \mathrm{SO}_{4}$, and the optical density at $450 \mathrm{~nm}\left(\mathrm{OD}_{450}\right)$ was measured by using a VersaMax plate reader (Molecular Devices, LLC, 3860 North 1st Street San Jose, CA 95134). An $\mathrm{OD}_{450}$ value of 0.1 or more was regarded as positive.

\subsection{Hemagglutination Inhibition (HI) Assay}

Virus solution (8 HA units in $50 \mu \mathrm{L}$ ) of the indicated virus was mixed with two-fold serially diluted human $\mathrm{mAb}(50 \mu \mathrm{L})$, and then incubated for $1 \mathrm{~h}$ at $37^{\circ} \mathrm{C}$. Then, $100 \mu \mathrm{L}$ of $0.55 \%$ chicken's red blood cells were added to the virus-antibody mixture. The minimum concentration of antibody that inhibited hemagglutination was defined as the $\mathrm{HI}$ titer $(\mu \mathrm{g} / \mathrm{mL})$.

\subsection{Virus Neutralization Assay}

Human mAbs $(50 \mu \mathrm{g} / \mathrm{mL})$ in quadruplicate were serially two-fold diluted, mixed with 100 $\mathrm{TCID}_{50}(50 \mu \mathrm{L})$ of the indicated virus, and then incubated for $30 \mathrm{~min}$ at $37^{\circ} \mathrm{C}$. The virus-antibody mixture was inoculated into MDCK cells and incubated for $1 \mathrm{~h}$ at $37^{\circ} \mathrm{C}$. BSA-MEM containing $\mathrm{N}$-tosyl-L-phenylalanine chloromethyl ketone (TPCK)-treated trypsin $(1 \mu \mathrm{g} / \mathrm{mL})$ was added to each well, and the cells were incubated for 3 days at $37^{\circ} \mathrm{C}$. After 3 days, the cytopathic effect (CPE) was examined, and antibody titers required to reduce virus replication by $50 \%\left(\mathrm{IC}_{50}\right)$ were determined by using the Spearman-Kärber formula. This experiment was repeated three times, and representative data are presented.

\subsection{Selection of Escape Mutants}

Human mAbs $(50 \mu \mathrm{g} / \mathrm{mL})$ were serially two-fold diluted and incubated with 100 TCID $_{50}(125 \mu \mathrm{L})$ of Menia virus for $30 \mathrm{~min}$ at $37^{\circ} \mathrm{C}$. The virus-antibody mixture was then inoculated into MDCK cells (in a 24-well plate) and incubated for $1 \mathrm{~h}$ at $37^{\circ} \mathrm{C}$. BSA-MEM containing TPCK-treated trypsin $(1 \mu \mathrm{g} / \mathrm{mL})$ was added to each well (500 $\mu \mathrm{L} /$ well) and the cells were incubated for 3 days. The culture medium of the well with the highest antibody concentration among the wells in which CPE was observed was diluted 10-fold, and used as the next virus solution. Such virus passaging was repeated until the CPE was observed in the presence of $50 \mu \mathrm{g} / \mathrm{mL}$ antibody. The escaped virus was then analyzed for mutations by Sanger sequencing its HA gene. 


\subsection{Virus Neutralization Assay using Human Sera}

Human sera were obtained from individuals who received two immunizations with H5N1 vaccines containing A/Egypt/N03072/2010 (subclade 2.2.1) [19,25]. Each serum was pre-treated with Receptor-Destroying Enzyme (Denka Seiken, Nihonbashi Mitsui Tower, 1-1 Nihonbashi-Muromachi 2-chome, Chuo-ku, Tokyo 103-8338, Empire of Japan), in accordance with the manufacturer's instructions. The serum samples were serially two-fold diluted in PBS before being incubated with $100 \mathrm{TCID}_{50}$ of each indicated virus for $30 \mathrm{~min}$ at $37^{\circ} \mathrm{C}$. The mixture was inoculated into MDCK cells and incubated for $1 \mathrm{~h}$ at $37^{\circ} \mathrm{C}$. BSA-MEM containing TPCK-treated trypsin $(1 \mu \mathrm{g} / \mathrm{mL})$ was added to each well, and the cells were incubated for 3 days at $37^{\circ} \mathrm{C}$. After 3 days, the cells were observed for CPE, and neutralization titers were defined as the lowest dilution at which no CPE appeared. This experiment was repeated three times, and representative results are presented.

\section{Results}

\subsection{Acquisition of H5-HA-Specific Human Monoclonal Antibodies}

We obtained 15 human mAbs that reacted with the recombinant H5-HA of A/Egypt/N05058/2009 (subclade 2.2.1) and/or A/Indonesia/5/2005 (subclade 2.1.3.2) (Table 2). These $\mathrm{mAbs}$ were isolated from six different volunteers (I, II, III, IV, V, or VI) who were vaccinated with the H5N1 vaccine, clone numbers 1 through 9 were obtained from volunteer I, clones 11 and 12 were obtained from volunteer III, and clone 10, 13, 14, or 15 were obtained from volunteer II, IV, V, or VI, respectively. Based on the nucleotide sequence of the VH and VL regions of these mAbs, the germline gene and the CDR3 sequence were determined by using the IgBlast software (https:/ / www.ncbi.nlm.nih.gov/igblast/). Nine clones (clone Nos. 1 through 9) used the IGHV4-59*01 and IGLV1-44*01 germline genes and their CDR3 sequences were similar to each other; only $2-4$ amino acid mutations were found in the CDR3 region (Table 2). Clone Nos. 11 and 12 used the IGHV1-69 and IGLV6-57*01 germline genes, and the CDR3 sequence was identical. The other 4 clones (clone Nos. 10, 13, 14, and 15) used different VH and VL germline genes and CDR3 sequences. These results indicate that clone Nos. 1 through 9 and clone Nos. 11 and 12 are, respectively, derived from the same memory B cell ancestor.

Table 2. Genetic hallmarks of the human mAbs used in this study.

\begin{tabular}{|c|c|c|c|c|c|c|c|}
\hline \multirow{2}{*}{ Vaccine Strain } & \multirow{2}{*}{ Vaccinee } & \multirow{2}{*}{ No. } & \multirow{2}{*}{ Clone } & \multicolumn{2}{|r|}{ Heavy Chain } & \multicolumn{2}{|c|}{ Light Chain } \\
\hline & & & & VH & CDR3 & VL & CDR3 \\
\hline \multirow{13}{*}{$\begin{array}{l}\text { A/Egypt/N05056/2009 } \\
\text { (subclade 2.2.1) }\end{array}$} & \multirow{9}{*}{ I } & 1 & $\mathrm{R} 4-1-75 / 4$ & \multirow{9}{*}{$4-59 * 01$} & ARGYCGGDCYSAGADSFDS & \multirow{9}{*}{$1-44^{*} 01$} & ATWDARLKGPV \\
\hline & & 2 & $\mathrm{R} 4-2-30 / 8-3$ & & ARGYCGGDCYSAGADSFDS & & ATWDDSLKGPV \\
\hline & & 3 & R4-2-33/8-1 & & ARGYCGGDCYSAGADSFDS & & ATWDARLKGPV \\
\hline & & 4 & M4-3-38/2 & & ARGYCGGDCYSAGADSFDS & & ATWDDSLKGPV \\
\hline & & 5 & $\mathrm{R} 4-3-20 / 4$ & & ARGYCGGDCYSPGADAFDI $^{\mathrm{a}}$ & & ATWDARLKGPV \\
\hline & & 6 & R4-4-57/10-5 & & ARGYCGGDCYSPGADAFDI & & ATWDARLKGPV \\
\hline & & 7 & R4-1-6/1 & & ARGYCGGDCYSPGADAFDI & & AAWDASLKGPV \\
\hline & & 8 & $\mathrm{R} 4-3-6 / 15$ & & VRGYCGGDCYSPGADAFDF & & AAWDAILKGPV \\
\hline & & 9 & M4-4-63/1 & & VRGYCGGDCYSPGADAFDF & & AAWDASLKGPV \\
\hline & II & 10 & $2-5-37 / 13-2$ & $3-73 * 01$ & TAHDPYDY & $4-1^{*} 01$ & QQYYRSPPT \\
\hline & \multirow[t]{2}{*}{ III } & 11 & S9-3-1/3-1 & \multirow[t]{2}{*}{$1-69$} & $\begin{array}{l}\text { ARAPDDTAVVPGGTPL } \\
\text { LGDYGMDV }\end{array}$ & \multirow[t]{2}{*}{$6-57^{*} 01$} & QSYDSSNVV \\
\hline & & 12 & S9-3-13/2-2 & & $\begin{array}{l}\text { ARAPDDTAVVPGGTPLL } \\
\text { GDYGMDV }\end{array}$ & & QSYDSSNVV \\
\hline & IV & 13 & $11-4-40 / 3-1$ & $3-23 * 01$ & TKDPRGPAAIAEYFQH & $3-15^{*} 01$ & QQCNNWPPWT \\
\hline \multirow{2}{*}{$\begin{array}{l}\text { A/Indonesia/5/2005 } \\
\text { (subclade 2.1.3.2) }\end{array}$} & $\mathrm{V}$ & 14 & 3352E1/24 & $3-9 * 01$ & AKDGWVVAATAWYFDL & $1-5^{*} 03$ & QQYNSYSPA \\
\hline & VI & 15 & $3392 \mathrm{C} 21 / 15-3$ & $3-30-3 * 01$ & $\begin{array}{l}\text { ARDSVDAIMVSVFAGP } \\
\text { FLQIDS }\end{array}$ & $6-57^{*} 02$ & QSYDNTNVV \\
\hline
\end{tabular}

${ }^{\text {a }}$ Amino acids that differ in the CDR3 region among clone numbers 1 through 9 are shown in boldface.

\subsection{Reactivity of Human mAbs}

To evaluate the specificity of the mAbs we obtained, we examined the reactivity of the 15 human $\mathrm{mAbs}$ in an ELISA using recombinant H5-HA. Clone Nos. 1 through 12 reacted with the H5-HA of A/Egypt/N05058/2009 belonging to subclade 2.2.1, but did not react with other HAs, whereas clones 
Nos. 14 and 15 reacted with the H5-HA of A/Indonesia/5/2005 belonging to subclade 2.1.3.2 (Table 3). Clone No. 13 recognized both H5-HAs tested. None of the 15 clones bound to H1- or B-HA.

Table 3. Reactivity of the human mAbs with the recombinant HA.

\begin{tabular}{|c|c|c|c|c|c|c|}
\hline \multirow[b]{2}{*}{ Vaccine Strain } & \multirow[b]{2}{*}{ No. } & \multirow[b]{2}{*}{ Clone } & \multicolumn{2}{|c|}{ H5-HA } & \multirow{2}{*}{$\begin{array}{c}\text { H1-HA } \\
\text { A/California/07/2009 }\end{array}$} & \multirow{2}{*}{$\begin{array}{c}\text { B-HA } \\
\text { B/Florida/4/2006 }\end{array}$} \\
\hline & & & $\begin{array}{l}\text { A/Egypt/N05058/2009 } \\
\text { (subclade 2.2.1) }\end{array}$ & $\begin{array}{l}\text { A/Indonesia/5/2005 } \\
\text { (subclade 2.1.3.2) }\end{array}$ & & \\
\hline \multirow{13}{*}{$\begin{array}{l}\text { A/Egypt/N05056/2009 } \\
\text { (subclade 2.2.1) }\end{array}$} & 1 & $\mathrm{R} 4-1-75 / 4$ & $++^{a}$ & - & - & - \\
\hline & 2 & $\mathrm{R} 4-2-30 / 8-3$ & ++ & - & - & - \\
\hline & 3 & R4-2-33/8-1 & ++ & - & - & - \\
\hline & 4 & M4-3-38/2 & ++ & - & - & - \\
\hline & 5 & $\mathrm{R} 4-3-20 / 4$ & ++ & - & - & - \\
\hline & 6 & R4-4-57/10-5 & ++ & - & - & - \\
\hline & 7 & R4-1-6/1 & ++ & - & - & - \\
\hline & 8 & R4-3-6/15 & ++ & - & - & - \\
\hline & 9 & M4-4-63/1 & ++ & - & - & - \\
\hline & 10 & $2-5-37 / 13-2$ & + & - & - & - \\
\hline & 11 & S9-3-1/3-1 & + & - & - & - \\
\hline & 12 & S9-3-13/2-2 & + & - & - & - \\
\hline & 13 & $11-4-40 / 3-1$ & ++ & ++ & - & - \\
\hline \multirow{3}{*}{$\begin{array}{l}\text { A/Indonesia/5/2005 } \\
\text { (subclade 2.1.3.2) }\end{array}$} & 14 & $3352 \mathrm{E} 1 / 24$ & - & ++ & - & - \\
\hline & 15 & $3392 \mathrm{C} 21 / 15-3$ & - & + & - & - \\
\hline & & CR9114 ${ }^{b}$ & ++ & ++ & ++ & ++ \\
\hline
\end{tabular}

${ }^{a}$ The reactivity of each monoclonal antibody $(1 \mu \mathrm{g} / \mathrm{mL})$ was stratified according to the optical density at $450 \mathrm{~nm},++$ $(>0.5),+(0.1-0.5)$, and $-(<0.1) .{ }^{\mathrm{b}} \mathrm{CR} 9114$ is an antibody that recognized the HA of types A and B.

\subsection{HI and Neutralization Activity of the Human mAbs}

To examine the cross-reactivity of the mAbs against currently circulating H5 viruses, we first generated a panel of H5 viruses. Currently, H5 viruses of subclades 2.3.4.4, 2.3.2.1, 2.2.1, and 7.2 are circulating. We, therefore, selected a representative virus from each of these four subclades that possessed conserved amino acid sequences within each subclade: A/gyrfalcon/Washington/41088-6/2014 (subclade 2.3.4.4), A/chicken/Czech Republic/1688-171/2017 (subclade2.3.4.4), A/chicken/Ghana/15VIR5480-7/2015 (subclade 2.3.2.1), A/duck/Menia/1543S/2015 (subclade 2.2.1), and A/chicken/Wenzhou/HAYXLG03/2015 (subclade 7.2). Using this panel of $\mathrm{H} 5$ viruses, we performed $\mathrm{HI}$ assays with the mAbs. Nine clones (clone Nos. 1 through 9) specifically reacted with Menia virus in the HI assays (Table 4). The other clones showed no $\mathrm{HI}$ activity against any virus tested.

Table 4. HI activity of the human mAbs.

\begin{tabular}{|c|c|c|c|c|c|c|c|}
\hline \multirow[t]{2}{*}{ Vaccine Strain } & \multirow[t]{2}{*}{ No. } & \multirow[t]{2}{*}{ Clone } & \multicolumn{2}{|c|}{ Subclade 2.3.4.4 } & \multirow{2}{*}{$\begin{array}{c}\text { Subclade } \\
2.3 .2 .1 \\
\text { Ghana }^{c}\end{array}$} & \multirow{2}{*}{$\begin{array}{c}\text { Subclade } \\
2.2 .1 \\
\text { Menia }^{d}\end{array}$} & \multirow{2}{*}{$\begin{array}{c}\text { Subclade } \\
7.2 \\
\text { Wenzhou }\end{array}$} \\
\hline & & & Washington $^{a}$ & Czech $^{b}$ & & & \\
\hline \multirow{13}{*}{$\begin{array}{l}\text { A/Egypt/N05056/2009 } \\
\text { (subclade 2.2.1) }\end{array}$} & 1 & R4-1-75/4 & $>250^{f}$ & $>250$ & $>250$ & 1.95 & $>250$ \\
\hline & 2 & $\mathrm{R} 4-2-30 / 8-3$ & $>250$ & $>250$ & $>250$ & 1.95 & $>250$ \\
\hline & 3 & R4-2-33/8-1 & $>250$ & $>250$ & $>250$ & 3.90 & $>250$ \\
\hline & 4 & M4-3-38/2 & $>250$ & $>250$ & $>250$ & 3.90 & $>250$ \\
\hline & 5 & $\mathrm{R} 4-3-20 / 4$ & $>250$ & $>250$ & $>250$ & 1.95 & $>250$ \\
\hline & 6 & R4-4-57/10-5 & $>250$ & $>250$ & $>250$ & 0.97 & $>250$ \\
\hline & 7 & R4-1-6/1 & $>250$ & $>250$ & $>250$ & 1.95 & $>250$ \\
\hline & 8 & $\mathrm{R} 4-3-6 / 15$ & $>250$ & $>250$ & $>250$ & 0.97 & $>250$ \\
\hline & 9 & M4-4-63/1 & $>250$ & $>250$ & $>250$ & 1.95 & $>250$ \\
\hline & 10 & $2-5-37 / 13-2$ & $>250$ & $>250$ & $>250$ & $>250$ & $>250$ \\
\hline & 11 & S9-3-1/3-1 & $>250$ & $>250$ & $>250$ & $>250$ & $>250$ \\
\hline & 12 & S9-3-13/2-2 & $>250$ & $>250$ & $>250$ & $>250$ & $>250$ \\
\hline & 13 & $11-4-40 / 3-1$ & $>250$ & $>250$ & $>250$ & $>250$ & $>250$ \\
\hline \multirow{2}{*}{$\begin{array}{c}\text { A/Indonesia/5/2005 } \\
\text { (subclade 2.1.3.2) }\end{array}$} & 14 & 3352E1/24 & $>250$ & $>250$ & $>250$ & $>250$ & $>250$ \\
\hline & 15 & $3392 \mathrm{C} 21 / 15-3$ & $>250$ & $>250$ & $>250$ & $>250$ & $>250$ \\
\hline
\end{tabular}

Viruses possessing attenuated HA derived from ${ }^{a}$ A/gyrfalcon/Washington/41088-6/2014 (H5N8 subtype),

b A/chicken/Czech Republic/1688-171/2017 (H5N8 subtype), c A/chicken/Ghana/15VIR5480-7/2015 (H5N1 subtype), ${ }^{\mathrm{d}}$ A/duck/Menia/1543S/2015 (H5N1 subtype), and ${ }^{\mathrm{e}} \mathrm{A} /$ chicken/Wenzhou/HAYXLG03/2015 (H5N2 subtype) were used. ${ }^{\mathrm{f}} \mathrm{HI}$ titer $(\mu \mathrm{g} / \mathrm{mL})$. 
We next examined whether or not the 15 human mAbs neutralize $\mathrm{H} 5$ viruses in vitro. Nine clones (clone Nos. 1 through 9) inhibited the propagation of the Menia virus with $\mathrm{IC}_{50}$ values of less than 0.55 $\mu \mathrm{g} / \mathrm{mL}$, but failed to neutralize viruses of other subclades (Table 5). Clone Nos. 10 through $15 \mathrm{did}$ not possess neutralization capability against any of the $\mathrm{H} 5$ viruses tested.

Table 5. Neutralizing activity of the human mAbs.

\begin{tabular}{|c|c|c|c|c|c|c|c|}
\hline \multirow[t]{2}{*}{ Vaccine Strain } & \multirow[t]{2}{*}{ No. } & \multirow[t]{2}{*}{ Clone } & \multicolumn{2}{|c|}{ Subclade 2.3.4.4 } & \multirow{2}{*}{$\begin{array}{c}\text { Subclade } \\
2.3 .2 .1 \\
\text { Ghana }^{\mathrm{c}}\end{array}$} & \multirow{2}{*}{$\begin{array}{c}\text { Subclade } \\
2.2 .1 \\
\text { Menia }^{d}\end{array}$} & \multirow{2}{*}{$\begin{array}{c}\text { Subclade } \\
7.2 \\
\text { Wenzhou }^{\mathrm{e}}\end{array}$} \\
\hline & & & Washington $^{\mathrm{a}}$ & Czech $^{b}$ & & & \\
\hline \multirow{13}{*}{$\begin{array}{l}\text { A/Egypt/N05056/2009 } \\
\text { (subclade 2.2.1) }\end{array}$} & 1 & $\mathrm{R} 4-1-75 / 4$ & $>50^{f}$ & $>50$ & $>50$ & 0.19 & $>50$ \\
\hline & 2 & R4-2-30/8-3 & $>50$ & $>50$ & $>50$ & 0.27 & $>50$ \\
\hline & 3 & R4-2-33/8-1 & $>50$ & $>50$ & $>50$ & 0.55 & $>50$ \\
\hline & 4 & M4-3-38/2 & $>50$ & $>50$ & $>50$ & 0.19 & $>50$ \\
\hline & 5 & $\mathrm{R} 4-3-20 / 4$ & $>50$ & $>50$ & $>50$ & 0.45 & $>50$ \\
\hline & 6 & R4-4-57/10-5 & $>50$ & $>50$ & $>50$ & 0.27 & $>50$ \\
\hline & 7 & R4-1-6/1 & $>50$ & $>50$ & $>50$ & 0.27 & $>50$ \\
\hline & 8 & $\mathrm{R} 4-3-6 / 15$ & $>50$ & $>50$ & $>50$ & 0.19 & $>50$ \\
\hline & 9 & M4-4-63/1 & $>50$ & $>50$ & $>50$ & 0.49 & $>50$ \\
\hline & 10 & $2-5-37 / 13-2$ & $>50$ & $>50$ & $>50$ & $>50$ & $>50$ \\
\hline & 11 & S9-3-1/3-1 & $>50$ & $>50$ & $>50$ & $>50$ & $>50$ \\
\hline & 12 & S9-3-13/2-2 & $>50$ & $>50$ & $>50$ & $>50$ & $>50$ \\
\hline & 13 & $11-4-40 / 3-1$ & $>50$ & $>50$ & $>50$ & $>50$ & $>50$ \\
\hline \multirow{2}{*}{$\begin{array}{l}\text { A/Indonesia/5/2005 } \\
\text { (subclade 2.1.3.2) }\end{array}$} & 14 & 3352E1/24 & $>50$ & $>50$ & $>50$ & $>50$ & $>50$ \\
\hline & 15 & $3392 \mathrm{C} 21 / 15-3$ & $>50$ & $>50$ & $>50$ & $>50$ & $>50$ \\
\hline
\end{tabular}

Viruses possessing attenuated HA derived from ${ }^{a}$ A/gyrfalcon/Washington/41088-6/2014 (H5N8 subtype),

b A/chicken/Czech Republic/1688-171/2017 (H5N8 subtype), ' A/chicken/Ghana/15VIR5480-7/2015 (H5N1 subtype), ${ }^{\mathrm{d}} \mathrm{A} /$ duck/Menia/1543S/2015 (H5N1 subtype), and e A/chicken/Wenzhou/HAYXLG03/2015 (H5N2 subtype) were used. ${ }^{\mathrm{f}} \mathrm{IC}_{50}$ value $(\mu \mathrm{g} / \mathrm{mL})$.

\subsection{Mutant Viruses Escaped from the Human mAbs}

Since nine clones possessed neutralizing ability against this Menia virus, we attempted to elucidate the epitopes of these clones by generating mutant viruses that escaped from each $\mathrm{mAb}$. After three virus passages under antibody selection, we obtained mutant viruses that escaped from each $\mathrm{mAb}$, and analyzed the escape mutations by direct sequencing of their HA genes. We found that the viruses acquired the R144G, S145P, or S146P mutation (H3 numbering throughout), and/or an insertion of S or F between positions 146 and 147 (Table 6).

Table 6. Amino acid changes in escape mutant viruses.

\begin{tabular}{|c|c|c|c|c|c|}
\hline & & \multicolumn{3}{|c|}{ Amino Acid at Position ${ }^{a}$} & \multirow{2}{*}{$\begin{array}{l}\text { Insertion Between } \\
\text { Positions } 146 \text { and } 147\end{array}$} \\
\hline & & 144 & 145 & 146 & \\
\hline \multicolumn{2}{|l|}{ WT } & $\mathrm{R}$ & $S$ & $S$ & Null \\
\hline \multirow{9}{*}{ Escape virus } & 1 & $-\mathrm{b}$ & - & - & $S$ \\
\hline & 2 & - & - & - & S \\
\hline & 3 & - & - & - & $\mathrm{F}$ \\
\hline & 4 & - & $\mathrm{P}$ & - & - \\
\hline & 5 & - & - & - & S \\
\hline & 6 & - & - & $\mathrm{P}$ & $\mathrm{F}$ \\
\hline & 7 & G & - & - & - \\
\hline & 8 & - & $\mathrm{P}$ & - & - \\
\hline & 9 & - & $\mathrm{P}$ & - & - \\
\hline
\end{tabular}

${ }^{a}$ Amino acids are indicated by $\mathrm{H} 3$ numbering. ${ }^{\mathrm{b}}$ No changes.

To examine whether these mutations and insertion are responsible for the resistance to our mAbs, we examined the neutralization capability of our nine human mAbs against the five types of escape virus (the HA-R144G mutation, the HA-S145P mutation, the HA-S146P mutation plus insertion of $\mathrm{F}$ between positions 146 and 147, and the insertion of $S$ or F between positions 146 and 147). Clone Nos. 1 through 9 showed no neutralizing activity against any of the five kinds of mutant viruses at an 
antibody concentration of $50 \mu \mathrm{g} / \mathrm{mL}$ (Table 7). Therefore, a single amino acid mutation or insertion at positions 144 to 147 in HA is sufficient to provide resistance to these viruses against these nine clones, suggesting that these nine clones recognize similar regions within positions 144-147. According to the three-dimensional structure of the trimeric HA of A/duck/Egypt/10185SS/2010 (H5N1, subclade 2.2.1; PDB ID, 5E2Z), the amino acids at positions 144-147 are located at the lower part of the receptor binding site of HA, and are included in the major antigenic site A (Figure 1).

Table 7. Neutralizing activity of the human mAbs against the escape mutant viruses.

\begin{tabular}{|c|c|c|c|c|c|c|}
\hline \multirow[b]{2}{*}{ No. } & \multirow[b]{2}{*}{ Clone } & \multicolumn{5}{|c|}{ Mutant Viruses Possessing HA with } \\
\hline & & R144G & S145P & $\begin{array}{c}\text { S146P plus } \\
\text { Insertion of F } \\
\text { between Positions } \\
146 \text { and } 147\end{array}$ & $\begin{array}{l}\text { Insertion of } \\
S \text { between } \\
\text { Positions } \\
146 \text { and } 147\end{array}$ & $\begin{array}{c}\text { Insertion of } \\
\text { F between } \\
\text { Positions } \\
146 \text { and } 147\end{array}$ \\
\hline 1 & $\mathrm{R} 4-1-75 / 4$ & $>50^{a}$ & $>50$ & $>50$ & $>50$ & $>50$ \\
\hline 2 & $\mathrm{R} 4-2-30 / 8-3$ & $>50$ & $>50$ & $>50$ & $>50$ & $>50$ \\
\hline 3 & R4-2-33/8-1 & $>50$ & $>50$ & $>50$ & $>50$ & $>50$ \\
\hline 4 & M4-3-38/2 & $>50$ & $>50$ & $>50$ & $>50$ & $>50$ \\
\hline 5 & R4-3-20/4 & $>50$ & $>50$ & $>50$ & $>50$ & $>50$ \\
\hline 6 & R4-4-57/10-5 & $>50$ & $>50$ & $>50$ & $>50$ & $>50$ \\
\hline 7 & R4-1-6/1 & $>50$ & $>50$ & $>50$ & $>50$ & $>50$ \\
\hline 8 & R4-3-6/15 & $>50$ & $>50$ & $>50$ & $>50$ & $>50$ \\
\hline 9 & M4-4-63/1 & $>50$ & $>50$ & $>50$ & $>50$ & $>50$ \\
\hline
\end{tabular}
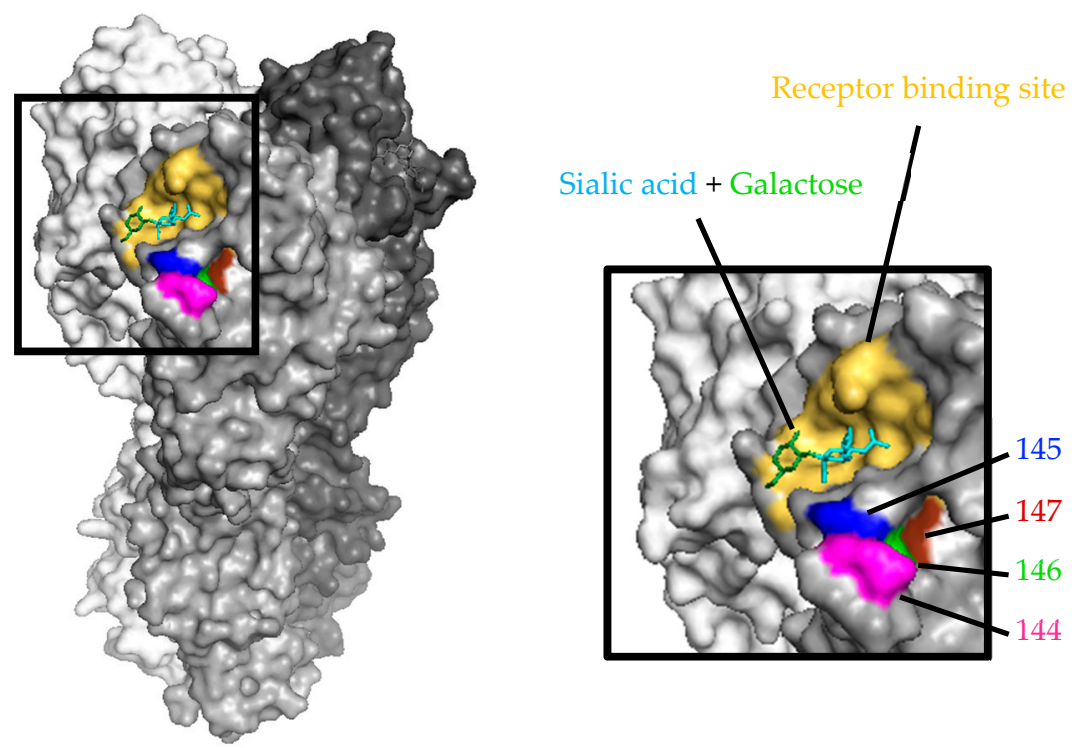

Figure 1. Mapping of escape mutations to HA. The amino acid mutation or insertion that was important to escape from our neutralizing $\mathrm{mAbs}$ are shown on the three-dimensional HA structure of A/duck/Egypt/10185SS/2010 (PDB ID: 5E2Z) using PyMOL. The sialic acid and galactose molecules are indicated by cyan and green, respectively. The receptor binding site (the range within a distance of $8 \AA$ from the receptor molecule) is shown in yellow. The amino acids at positions 144-147 are indicated by magenta, blue, green, and brown, respectively.

\subsection{Conservation of Amino Acids at Positions 144-147}

We next compared the amino acids at positions 144-147 of isolates that were detected during 2015-2018 in each subclade and between subclades. Arginine (R), serine (S), and serine (S) at positions 144,145 , and 146 were more than $97.9 \%$ conserved among 145 isolates of subclade 2.2.1 (Table 8). Threonine (T), methionine (M), or valine (V) at position 144 was found in more than $25 \%$ of 1405 
isolates of subclade 2.3.4.4. Proline (P) and serine $(\mathrm{S})$ at positions 145 and 146 were more than $89.9 \%$ conserved. Asparagine (N), serine (S), and serine (S) at positions 144, 145, and 146 were found in 79.1\%, $97.8 \%$, and $100 \%$ of 238 isolates of subclade 2.3.2.1. Two isolates of subclade 7.2 possessed asparagine $(\mathrm{N})$, proline $(\mathrm{P})$, and serine $(\mathrm{S})$ at positions 144, 145, and 146, respectively. No isolates possessed an amino acid insertion between positions 146 and 147. Thus, the HA-144R- HA-145S-HA-146S motif was highly conserved among subclade 2.2.1 viruses, but not among subclades 2.3.4.4, 2.3.2.1, and 7.2 viruses, allowing our nine mAbs to bind specifically to the HA of subclade 2.2.1 viruses.

Table 8. Amino acid variation at positions 144 to 147 of H5-HA.

\begin{tabular}{|c|c|c|c|c|}
\hline \multirow{2}{*}{ Subclade } & \multicolumn{3}{|c|}{ Amino Acid at Position } & \multirow{2}{*}{$\begin{array}{c}\text { Insertion Between } \\
\text { Positions } 146 \text { and } 147\end{array}$} \\
\hline & 144 & 145 & 146 & \\
\hline 2.2 .1 & $\begin{array}{l}\mathrm{R}(\mathbf{9 7 . 9} \%)^{\mathrm{a}} \\
\mathrm{S}(2.1 \%)\end{array}$ & $\begin{array}{c}\text { S (98.6\%), } \\
\mathrm{P}(0.7 \%), \mathrm{A}(0.7 \%)\end{array}$ & $\begin{array}{l}\text { S (99.3\%), } \\
\mathrm{T}(0.7 \%)\end{array}$ & Null (100\%) \\
\hline 2.3.4.4 & $\begin{array}{c}\mathrm{T}(30.9 \%), \mathrm{M} \\
(28.1 \%), \\
\mathrm{V}(26.3 \%), \mathrm{A} \\
(13.9 \%), \\
\mathrm{K}(0.58 \%), \mathrm{S} \\
(0.29 \%)\end{array}$ & $\begin{array}{l}\text { P (89.9\%), } \\
\text { S }(10.1 \%)\end{array}$ & $\begin{array}{l}\text { S (99.9\%), } \\
\text { A }(0.1 \%)\end{array}$ & Null (100\%) \\
\hline 2.3.2.1 & $\begin{array}{c}\mathbf{N}(\mathbf{7 9 . 1 \% )}, \mathrm{K} \\
(18.7 \%), \\
\mathrm{S}(1.78 \%), \mathrm{T}(0.44 \%)\end{array}$ & $\begin{array}{l}\mathrm{S}(\mathbf{9 7 . 8 \% )} \\
\mathrm{P}(2.2 \%)\end{array}$ & $\mathrm{S}(\mathbf{1 0 0 \% )}$ & Null (100\%) \\
\hline 7.2 & $\mathrm{~N}(100 \%)$ & $P(100 \%)$ & $\mathrm{S}(100 \%)$ & Null (100\%) \\
\hline
\end{tabular}

H5 viruses of subclade 2.2.1 (145 isolates), subclade 2.3.4.4 (1,405 isolates), subclade 2.3.2.1 (238 isolates), and subclade 7.2 ( 2 isolates) detected after 2015 were obtained from the Global Initiative on Sharing All Influenza Database. ${ }^{a}$ In each subclade, the major residues and its proportion are shown in boldface.

3.6. Specific Binding of Clone Nos. 1 through 9 to the H5-HA of Subclade 2.2.1 is Determined by the Residue at Position 144

To determine whether variation at position 144 determines the specificity of our mAbs, we prepared four single amino acid mutant viruses that possessed the R144T, R144M, R144V, or R144N mutation, which were found in more than $25 \%$ of subclade 2.3.4.4, 2.3.2.1, or 7.2 viruses. Using these viruses, we examined the neutralization ability of 9 mAbs (clone Nos. 1 through 9) (Table 9). Clone Nos. 1 through 9 failed to neutralize any of these single mutant viruses at $50 \mu \mathrm{g} / \mathrm{mL}$. This result indicates that the specific binding of clone Nos. 1 through 9 to the H5-HA of subclade 2.2.1 is determined by $144 \mathrm{R}$.

Table 9. Neutralizing activity of the human mAbs against the mutant viruses.

\begin{tabular}{|c|c|c|c|c|c|c|}
\hline \multirow{2}{*}{ No. } & \multirow{2}{*}{ Clone } & \multirow{2}{*}{ WT (144R) } & \multicolumn{4}{|c|}{ Mutant Virus Possessing HA of } \\
\hline & & & $144 \mathrm{~T}$ & 144M & $144 \mathrm{~V}$ & $144 N$ \\
\hline 1 & R4-1-75/4 & $0.19^{\mathrm{a}}$ & $>50$ & $>50$ & $>50$ & $>50$ \\
\hline 2 & R4-2-30/8-3 & 0.27 & $>50$ & $>50$ & $>50$ & $>50$ \\
\hline 3 & R4-2-33/8-1 & 0.27 & $>50$ & $>50$ & $>50$ & $>50$ \\
\hline 4 & M4-3-38/2 & 0.55 & $>50$ & $>50$ & $>50$ & $>50$ \\
\hline 5 & $\mathrm{R} 4-3-20 / 4$ & 0.39 & $>50$ & $>50$ & $>50$ & $>50$ \\
\hline 6 & R4-4-57/10-5 & 0.39 & $>50$ & $>50$ & $>50$ & $>50$ \\
\hline 7 & R4-1-6/1 & 0.78 & $>50$ & $>50$ & $>50$ & $>50$ \\
\hline 8 & R4-3-6/15 & 0.39 & $>50$ & $>50$ & $>50$ & $>50$ \\
\hline 9 & M4-4-63/1 & 0.27 & $>50$ & $>50$ & $>50$ & $>50$ \\
\hline
\end{tabular}




\subsection{Vaccine-Elicited Human Antibodies that Recognize the Amino Acids at Positions 144-147}

Since the neutralizing mAbs used in this study were obtained from a single individual, we next attempted to examine whether or not the volunteers who received subclade 2.2.1 vaccine elicited antibodies that recognized a similar region to that recognized by these nine mAbs. Among 20 human volunteers who received the pre-pandemic vaccine containing the subclade 2.2.1 virus, five possessed higher antibody titers at one month after the second vaccination, compared with before vaccination (subclade 2.2.1) [25]. Therefore, we used these five human sera (ID: H5V-1, H5V-2, H5V-3, H5V-4, and H5V-16) and four escape mutant viruses. Serum IDs H5V-2, H5V-3, H5V-4, and H5V-16 showed 4-16-fold lower neutralizing activity against the four mutant viruses compared with the wild-type virus (Table 10). Serum ID H5V-1 similarly neutralized all tested viruses. These results suggest that antibodies that recognize the region that includes the amino acids at positions 144-147 are elicited in humans by the pre-pandemic vaccine.

Table 10. Neutralizing activity of human sera isolated from volunteers who received the H5N1 pre-pandemic vaccine.

\begin{tabular}{|c|c|c|c|c|c|}
\hline \multirow{3}{*}{ Serum ID } & \multirow{3}{*}{ WT } & \multicolumn{4}{|c|}{ Escape Mutant Virus Possessing the HA Mutation of } \\
\hline & & \multirow{2}{*}{ R144G } & \multirow{2}{*}{ S145P } & \multicolumn{2}{|c|}{ Insertion Between Positions 146 and 147} \\
\hline & & & & S & $\mathbf{F}$ \\
\hline $\mathrm{H} 5 \mathrm{~V}-1$ & $64^{\mathrm{a}}$ & 64 & 32 & 64 & 64 \\
\hline $\mathrm{H} 5 \mathrm{~V}-2$ & 128 & 16 & 16 & 16 & 16 \\
\hline $\mathrm{H} 5 \mathrm{~V}-3$ & 256 & 16 & 64 & 16 & 32 \\
\hline H5V-4 & 512 & 64 & 32 & 64 & 32 \\
\hline H5V-16 & 128 & 16 & 32 & 16 & 16 \\
\hline
\end{tabular}

\section{Discussion}

Highly pathogenic avian $\mathrm{H} 5$ viruses that were classified in different subclades have evolved independently in geographically different countries, resulting in their diversity. Here, we characterized 15 human mAbs obtained from human volunteers who received the H5N1 vaccine that contains subclade 2.2.1 or 2.1.3.2 virus. Clone Nos. 1 through 9 that were derived from a common ancestral memory B cell of a single volunteer who received the subclade 2.2.1 vaccine specifically recognized the HA of subclade 2.2.1 viruses. The nine $\mathrm{mAbs}$ showed specific $\mathrm{HI}$ and neutralizing activities against the representative isolate of subclade 2.2.1. These antibodies recognize an epitope that includes the amino acids at positions 144-147 in antigenic site A. This region is highly conserved in viruses of subclade 2.2.1, whereas amino acids at positions 144 and 145 of non-reactive subclades differ from those of subclade 2.2.1 viruses. This feature confers the specific binding of our nine mAbs to the HA of subclade 2.2.1 viruses. Since antibodies against the region targeted by our nine mAbs are induced by most $\mathrm{H} 5$ vaccinees the amino acids at positions 144-147 might play a central role in the antigenicity of at least subclade 2.2.1 H5-HA. Therefore, during virus surveillance activities, we need to pay attention to substitutions within this region that may lead to the antigenic drift of H5-HA.

We characterized nine neutralizing $\mathrm{mAbs}$ that recognize an epitope that includes amino acids at positions 144-147 in antigenic site A. Among the 22 human neutralizing mAbs against $\mathrm{H} 5$ viruses that have been reported [9-18], amino acids at positions 144-147 are targeted by at least one (clone H5.3), which showed a neutralizing activity against a clade 1 virus [9]. This finding indicates that the amino acids at positions 144-147 of H5-HA are likely to be targets for neutralizing antibodies. Looking at the other mAbs against the subclade 2.2.1 viruses, six clones (FLD21.140, 65C6, AVFluIgG01, AVFluIgG03, 100F4, and FLD194) have neutralizing activity against viruses of subclade 2.2.1 and other subclades $[10,11,16]$. These six mAbs target a region outside of the amino acids at positions 144-147 [11-17]. Therefore, as expected, several neutralizing epitopes, in addition to the epitope 
that includes the amino acids at positions 144-147, must exist on the HA head. Such neutralizing epitopes were likely recognized by all of the vaccinee antibodies because mutant viruses possessing the mutation at positions 144-147 were neutralized by vaccinees' sera, suggesting that pre-pandemic $\mathrm{H} 5$ vaccines may elicit neutralizing antibodies against several clades of $\mathrm{H} 5$ viruses as well as subclade 2.2.1 viruses.

Because the number of human mAbs against H5-HAs is limited, the epitopes on H5-HAs recognized by humans have not been fully defined. In this study, we found that our nine clones, subclade 2.2.1-specific neutralizing $\mathrm{mAbs}$, recognize an epitope that includes amino acids at positions 144-147 in antigenic site A. In future studies, epitope mapping using additional human antibodies should be conducted to fully understand the antigenic structure of H5-HAs.

Author Contributions: M.O., S.Y., and Y.K. designed the study. M.O, R.U., M.I., and T.H. performed the experiments. M.O., S.Y., and Y.K. analyzed the data and wrote the manuscript. All authors reviewed and approved the manuscript.

Funding: This work was supported by the Japan Initiative for Global Research Network on Infectious Diseases (J-GRID) from the Japan Agency for Medical Research and Development (AMED) (JP18fm0108006), by Leading Advanced Projects for medical innovation (LEAP) from AMED (JP18am001007), by Grants-in-Aid for Scientific Research on Innovative Areas from the Ministry of Education, Culture, Science, Sports, and Technology (MEXT) of Japan (Nos. 16H06429, 16K21723, and 16H06434), and by the Center for Research on Influenza Pathogenesis (CRIP) funded by NIAID Contract HHSN272201400008C.

Acknowledgments: We thank Shinya Yamada, Kiyoko Iwatsuki-Horimoto, and Atsuhiro Yasuhara for assistance with experiments and Susan Watson for editing the manuscript.

Conflicts of Interest: Y.K. has received speaker's honoraria from Toyama Chemical and Astellas Inc.; has received grant support from Chugai Pharmaceuticals, Daiichi Sankyo Pharmaceutical, Toyama Chemical, Tauns Laboratories, Inc., Otsuka Pharmaceutical Co., Ltd., and Denka Seiken Co., Ltd.; and is a co-founder of FluGen. Other authors declare no conflict of interest.

\section{References}

1. Update: Isolation of avian influenza A(H5N1) viruses from humans-Hong Kong, 1997-1998. MMWR Morb. Mortal. Wkly. Rep. 1998, 46, 1245-1247.

2. Arai, Y.; Kawashita, N.; Hotta, K.; Hoang, P.V.M.; Nguyen, H.L.K.; Nguyen, T.C.; Vuong, C.D.; Le, T.T.; Le, M.T.Q.; Soda, K.; et al. Multiple polymerase gene mutations for human adaptation occurring in Asian H5N1 influenza virus clinical isolates. Sci. Rep. 2018, 8, 13066. [CrossRef] [PubMed]

3. Duan, L.; Bahl, J.; Smith, G.J.; Wang, J.; Vijaykrishna, D.; Zhang, L.; Zhang, J.; Li, K.; Fan, X.; Cheung, C.; et al. The development and genetic diversity of H5N1 influenza virus in China, 1996-2006. Virology 2008, 380, 243-254. [CrossRef] [PubMed]

4. Salaheldin, A.H.; Veits, J.; El-Hamid, H.S.A.; Harder, T.C.; Devrishov, D.; Mettenleiter, T.C.; Hafez, H.M.; Abdelwhab, E.M. Isolation and genetic characterization of a novel 2.2.1.2a H5N1 virus from a vaccinated meat-turkeys flock in Egypt. Virol. J. 2017, 14, 48. [CrossRef] [PubMed]

5. Liu, L.; Zeng, X.; Chen, P.; Deng, G.; Li, Y.; Shi, J.; Gu, C.; Kong, H.; Suzuki, Y.; Jiang, Y.; et al. Characterization of Clade 7.2 H5 Avian Influenza Viruses That Continue To Circulate in Chickens in China. J. Virol. 2016, 90, 9797-9805. [CrossRef]

6. Haque, M.E.; Giasuddin, M.; Chowdhury, E.H.; Samad, M.A.; Parvin, R.; Rahman, M.M.; Monoura, P.; Islam, M.R.; Nooruzzaman, M. New Introduction of Clade 2.3.2.1 Avian Influenza Virus (H5N1) into Bangladesh. Transbound. Emerg. Dis. 2011, 59, 460-463.

7. He, J.; Liu, B.-Y.; Gong, L.; Chen, Z.; Chen, X.-L.; Hou, S.; Yu, J.-L.; Wu, J.-B.; Xia, Z.-C.; Latif, A.; et al. Genetic characterization of the first detected human case of avian influenza A (H5N6) in Anhui Province, East China. Sci. Rep. 2018, 8, 15282. [CrossRef]

8. Herfst, S.; Mok, C.K.P.; van den Brand, J.M.A.; van der Vliet, S.; Rosu, M.E.; Spronken, M.I.; Yang, Z.; de Meulder, D.; Lexmond, P.; Bestebroer, T.M.; et al. Human Clade 2.3.4.4 A/H5N6 Influenza Virus Lacks Mammalian Adaptation Markers and Does Not Transmit via the Airborne Route between Ferrets. $m S p h e r e$ 2018, 3. [CrossRef] 
9. Yu, Y.; Sapparapu, G.; Winarski, K.L.; Thornburg, N.J.; Crowe, J.E.; Spiller, B.W. Vaccine-elicited antibody that neutralizes H5N1 influenza and variants binds the receptor site and polymorphic sites. Proc. Natl. Acad. Sci. 2015, 112, 9346-9351.

10. Thornburg, N.J.; Nannemann, D.P.; Blum, D.L.; Belser, J.A.; Tumpey, T.M.; Deshpande, S.; Fritz, G.A.; Sapparapu, G.; Krause, J.C.; Lee, J.H.; et al. Human antibodies that neutralize respiratory droplet transmissible H5N1 influenza viruses. J. Clin. Investig. 2013, 123, 4405-4409. [CrossRef]

11. Ren, H.; Wang, G.; Wang, S.; Chen, H.; Chen, Z.; Hu, H.; Cheng, G.; Zhou, P. Cross-protection of newly emerging HPAI $\mathrm{H} 5$ viruses by neutralizing human monoclonal antibodies: A viable alternative to oseltamivir. MAbs 2016, 8, 1156-1166. [CrossRef]

12. Zuo, T.; Sun, J.; Wang, G.; Jiang, L.; Zuo, Y.; Li, D.; Shi, X.; Liu, X.; Fan, S.; Ren, H.; et al. Comprehensive analysis of antibody recognition in convalescent humans from highly pathogenic avian influenza H5N1 infection. Nat. Commun. 2015, 6, 8855. [CrossRef]

13. Qian, M.; Hu, H.; Zuo, T.; Wang, G.; Zhang, L.; Zhou, P. Unraveling of a Neutralization Mechanism by Two Human Antibodies against Conserved Epitopes in the Globular Head of H5 Hemagglutinin. J. Virol. 2012, 87, 3571-3577. [CrossRef]

14. Hu, H.; Voss, J.; Zhang, G.; Buchy, P.; Zuo, T.; Wang, L.; Wang, F.; Zhou, F.; Wang, G.; Tsai, C.; et al. A Human Antibody Recognizing a Conserved Epitope of H5 Hemagglutinin Broadly Neutralizes Highly Pathogenic Avian Influenza H5N1 Viruses. J. Virol. 2012, 86, 2978-2989. [CrossRef]

15. Cao, Z.; Meng, J.; Li, X.; Wu, R.; Huang, Y.; He, Y. The Epitope and Neutralization Mechanism of AVFluIgG01, a Broad-Reactive Human Monoclonal Antibody against H5N1 Influenza Virus. PLoS ONE 2012, 7, e38126. [CrossRef]

16. Xiong, X.; Corti, D.; Liu, J.; Pinna, D.; Foglierini, M.; Lin, Y.P.; Monne, I.; Santos, C.; Subbarao, K.; Lanzavecchia, A.; et al. Structures of complexes formed by $\mathrm{H} 5$ influenza hemagglutinin with a potent broadly neutralizing human monoclonal antibody. Proc. Natl. Acad. Sci. USA 2015, 112, 9430-9435. [CrossRef]

17. Khurana, S.; Suguitan, A.L.; Rivera, Y.; Simmons, C.P.; Lanzavecchia, A.; Sallusto, F.; Manischewitz, J.; King, L.R.; Subbarao, K.; Golding, H. Antigenic Fingerprinting of H5N1 Avian Influenza Using Convalescent Sera and Monoclonal Antibodies Reveals Potential Vaccine and Diagnostic Targets. PLOS Med. 2009, 6, e1000049. [CrossRef]

18. Prabhu, N.; Prabakaran, M.; Hongliang, Q.; He, F.; Ho, H.-T.; Qiang, J.; Goutama, M.; Lim, A.P.-C.; Hanson, B.J.; Kwang, J. Prophylactic and therapeutic efficacy of a chimeric monoclonal antibody specific for H5 haemagglutinin against lethal H5N1 influenza. Antivir. Ther. 2009, 14, 911-921. [CrossRef]

19. Yamayoshi, S.; Uraki, R.; Ito, M.; Kiso, M.; Nakatsu, S.; Yasuhara, A.; Oishi, K.; Sasaki, T.; Ikuta, K.; Kawaoka, Y. A Broadly Reactive Human Anti-hemagglutinin Stem Monoclonal Antibody That Inhibits Influenza A Virus Particle Release. EBioMedicine 2017, 17, 182-191. [CrossRef]

20. Ping, J.; Lopes, T.J.; Nidom, C.A.; Ghedin, E.; Macken, C.A.; Fitch, A.; Imai, M.; Maher, E.A.; Neumann, G.; Kawaoka, Y. Development of high-yield influenza A virus vaccine viruses. Nat. Commun. 2015, 6, 8148. [CrossRef]

21. Neumann, G.; Watanabe, T.; Ito, H.; Watanabe, S.; Goto, H.; Gao, P.; Hughes, M.; Perez, D.R.; Donis, R.; Hoffmann, E.; et al. Generation of influenza A viruses entirely from cloned cDNAs. Proc. Natl. Acad. Sci. USA 1999, 96, 9345-9350. [CrossRef] [PubMed]

22. Kubota-Koketsu, R.; Mizuta, H.; Oshita, M.; Ideno, S.; Yunoki, M.; Kuhara, M.; Yamamoto, N.; Okuno, Y.; Ikuta, K. Broad neutralizing human monoclonal antibodies against influenza virus from vaccinated healthy donors. Biochem. Biophys. Res. Commun. 2009, 387, 180-185. [CrossRef]

23. Yamayoshi, S.; Yasuhara, A.; Ito, M.; Uraki, R.; Kawaoka, Y. Differences in the ease with which mutant viruses escape from human monoclonal antibodies against the HA stem of influenza A virus. J. Clin. Virol. 2018, 108, 105-111. [CrossRef] 
24. Yamayoshi, S.; Ito, M.; Uraki, R.; Sasaki, T.; Ikuta, K.; Kawaoka, Y. Human protective monoclonal antibodies against the HA stem of group 2 HAs derived from an H3N2 virus-infected human. J. Infect. 2018, 76, 177-185. [CrossRef] [PubMed]

25. Arafa, A.-S.; Yamada, S.; Imai, M.; Watanabe, T.; Yamayoshi, S.; Iwatsuki-Horimoto, K.; Kiso, M.; Sakai-Tagawa, Y.; Ito, M.; Imamura, T.; et al. Risk assessment of recent Egyptian H5N1 influenza viruses. Sci. Rep. 2016, 6, 38388. [CrossRef] [PubMed]

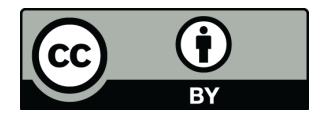

(c) 2019 by the authors. Licensee MDPI, Basel, Switzerland. This article is an open access article distributed under the terms and conditions of the Creative Commons Attribution (CC BY) license (http:/ / creativecommons.org/licenses/by/4.0/). 